\title{
Proposal of Biomass Heat Source for Microcogeneration Unit
}

Peter Ďurčanský1 ${ }^{1}$ Jozef Jandačka ${ }^{2}$

${ }^{1}$ Research Centre, University of Žilina, Univerzitná 1, 01026 Žilina, E-mail: peter.durcansky @ fstroj.uniza.sk

${ }^{2}$ Department of power engineering, Faculty of mechanical engineering, University of Žilina, Univerzitná 1, 01026 Žilina,

E-mail: jozef.jandacka@fstroj.uniza.sk

The use of renewable energy sources in Slovakia is currently very debated issue. The main cause of this discussion is the increase of energy prices, which increasingly burden the population and companies. The use of renewable sources, including biomass, represents an important contribution to solve this problem. When new heat source is designed, several technical regulations and recommendations must be followed. The proposed device is intended to serve for combustion of biomass, in the form of wood, of pellets. The aim of this work is to describe the design process of the combustion device as the main source of thermal energy in our proposed micro-cogeneration unit.

Keywords: Biomass, combustion, microcogeneration unit

\section{Acknowledgements}

This work is supported by the European Regional Development Fund and the State budget with project "Research Center of University of Zilina" ITMS 26220220183.

\section{References}

[1] ĎURČANSKÝ, P., JANDAČKA, J., KAPJOR, A., PAPUČÍK, Š. (2013). Návrh výmenníka tepla pre EricssonBraytonov motor, SKMTaT 2013, Tatranská Lomnica, Slovakia, p. 21-25

[2] Verein Deutscher Ingenieure, VDI heat atlas, Berlin Heidelberg: Springer-Verlag, 2010.

[3] LENHARD, R., MALCHO, M. (2013). Numerical simulation device for the transport of geothermal heat with forced circulation of media. in Mathematical and Computer Modelling, vol. 57, iss. 1-2, p. 111-125.

[4] CHABADOVÁ, J., PAPUČÍK, Š., NOSEK, R. (2014). Particle emissions from biomass combustion", XIX. the application of experimental and numerical methods in fluid mechanics and energetics 2014, Liptovský Ján, Slovakia 2014 , p. $67-70$

[5] NOSEK, R., HOLUBČÍK, M., PAPUČÍK, Š. (2014). Emission controls using different temperatures of combustion air, The scientific world journal, Vol.2014.

[6] SOUKUP, J., ŽMINDÁK, M., SKOČILAS, J., RYCHLÍKOVÁ, L. (2014). Application of Mesh-free Methods in Transient Dynamic Analysis of Orthotropic Plates, Manufacturing technology, Vol. 14, No. 3, ISSN 1213-2489

[7] SKOČILASOVÁ, B., SKOČILAS, J.(2013). Simulation of Liquid Flow in Pipe, Manufacturing technology, Vol. 13, No. 4, ISSN 1213-2489 